\title{
Digital equity: Considering the needs of staff as a social justice issue
}

\author{
Julie Willems \\ Monash University, Australia
}

\begin{abstract}
The rollout of technological advances in tertiary teaching and learning continues unabated. Concerns around staff lag in acceptance and adoption may overlook hidden influences. While considerations to address the digital divide and digital equity for tertiary students has been a growing social justice issue since the $1980 \mathrm{~s}$, what of the academic and professional staff who facilitate their teaching and learning? They are the other side of the coin and, as a cohort, are as diverse as the students they teach. Today, building staff capacity in the implementation of technology in teaching and learning in higher education still remains a key need. Yet a onesize-fits-all approach may miss the differing needs, views and capabilities of staff. It may also be built and developed upon explicit assumptions relating to staff access, skills and ability. For an equity-based approach to building staff capacity through professional development, empathy is required in purveying staff values, abilities, and needs. To address such issues and empower staff, a robust professional development program on digital technology is but one means to help stem the digital divide between staff haves and havenots.
\end{abstract}

\section{Implications for practice or policy:}

- The rapid change in technology enhanced learning will impact the professional development needs of educators.

- The inequities of digital participation and access for staff should be addressed to ensure successful practice.

- Many factors impact staff acceptance and adoption of technology, which in turn impact practice.

- Care is necessary to ensure that the digital divide does not marginalise those tasked with contributing to the successful learning outcomes of students.

- An environment that is conducive to the emergence of empathy is necessary to facilitate staff learning.

Keywords: staff professional development, technology, higher education, faculty development, capacity building, equity, empathy

\section{Introduction}

Picture this scene. Jo has an idea of adopting a newly released technology software and repurposing it to help teach in her unit, alongside and in addition to the university-mandated suite of technologies. She shares the idea at a monthly teaching and learning committee meeting in her faculty, at which she is one of the representative academics. Her vision is enthralling; her enthusiasm fills the room. Ben finds Jo's idea very interesting and says that he would be interested to learn more about the experiment in view of trialling it in his own unit the following semester. He asks Jo if he could come to talk with her more and also observe the application in use as she rolls it out. Viv says that Jo's integration of the new technology sounds interesting, but where is the proof that it will make a difference and enhance student learning? Viv also wants to know how a potential larger scale rollout would be funded if everyone adopted it. She also questions how staff would be taught how to use yet another new technology and, more importantly, would the students find this addition advantageous or cumbersome? She argues that a lot of infrastructure and support would be necessary for the new adoption. Jo listens intently. Then Dianne contributes to the discussion. She says that given her workload struggles, plus the huge amount of technological change that the university has already been through over the past few years, she would be reluctant to introduce any such change for her unit. Dianne goes through the list of changes that she has grappled with, from the introduction of a new learning management system as a major technology requiring migration of preexisting units, along with mandatory quality assurances in the design, overlaid by limited support and which has not factored in her extended personal circumstances, including lack of Internet connectivity on her 5- 
hour daily commute to and from work. Finally, George says that there is no need to introduce the technology at all in order to teach the concepts to the students and that talk of this is wasting valuable time in the meeting. George is the self-professed Luddite on the committee, not helped by some bad experiences he has had in trying to integrate the previous mandating of technology into his courses. He prefers face-toface teaching and is comfortable giving lectures.

Does this scenario sound vaguely familiar? It captures some of the staff voices that I have heard over the years and in various contexts. Technology is constantly changing and, alongside this, so too are its adoption and application to teaching and learning in higher education. This leads to multiple dilemmas, including a continuing lag around the globe as staff keep apace of this change of new technologies for teaching and learning (Daly, Pachler, \& Pelletier, 2009), and with implications for mandated technology rollouts.

One possible theory to understand this scenario around staff adoption and use of technology for teaching and learning in higher education is Rogers' (2003) diffusion of technological innovation model. This model identifies five adopter categories, noting that staff do not all adopt an innovation at the same time. Rogers' five categories, along with their suggested percentage of overall staff, along with an associated adjective, are $2.5 \%$ innovators (venturesome), $13.5 \%$ early adopters (respectable), $35 \%$ early majority (deliberate), $34 \%$ late majority (sceptical), and 16\% the laggards (traditional). Rogers' technological innovation model suggests therefore that the majority of staff are either deliberate or leisurely in their choice of technological use. New technology adoption rates by staff varies, and the narrative would suggest that Rogers' model is being evidenced.

While it would seem that Rogers' (2003) model explains what is being captured in the scenario of staff diversity, is this as simple as it seems? There are many factors behind staff acceptance and adoption of technology, and these need to be more carefully interrogated. Digital participation and access are not a level playing field, and this includes staff. Beyond a perception of reluctance of staff through either leisurely adoption of technology or deliberate lack of adoption, the same barriers that exist for student participation can also be at play for staff. Attention needs to be paid to the individual differences, backgrounds, and motivations of staff. It is important to listen to carefully and respond to voice, and narratives of voice, in order to identify and address the challenges. Indeed, upon closer inspection, the scenario above provides some hints that other factors may be at play. For this is a complex topic, and one that has implications for policy, leadership and practice (Adams Becker et al., 2018).

\section{Digital equity}

Through the lens of digital equity, rather than through the simplistic lens of Rogers' (2003) diffusion of technological innovation model, the following observations may be made. Jen, the innovator, has had access to technology, opportunity, skills, finances, Internet, other technologies, other people and resources, in order to be aware of the new technology and see its potentials for her students. She has been given opportunities to innovate before, and her confidence is high. Ben, as an early adopter, has also had opportunity. Not only is he a gamer with technological prowess but he has also taught the same classes for many years, has systems in place and has a great deal of time to explore alternative technologies. Viv, representing the early majority of technology rollout, is influenced by her peers and has had the benefit of building on some professional development along the way. Dianne, evoking the scepticism of the late majority is overwhelmed. She is a relative newcomer to the world of academia. Building content has been her main focus and sheer survival of the teaching and assessment cycles, as well as learning the basic technology of the institution, which has already changed multiple times since her arrival. Overlaying this, she has received limited support. Further, technological change has not been factored in her extended personal circumstances, including lack of Internet connectivity on her 5-hour daily commute to and from work as her train travels through terrain without Wi-Fi reception. She commutes a long way to and from the country every day to support her family as a single parent. She cannot afford to move to the city as her social support for the family is in the country. Her situation, however, is not simply a hurdle to overcome; rather, reluctance is a hurdle to be overcome rather than listened to empathetically, acknowledged, and engaged with. Dianne does not need to feel that she is a failure. Rather, it could be the systems, practices, and potentially institutional, and/or educational policies in place that are the issue. Finally, George, representative of the technological laggards in Rogers' model, the self-professed Luddite on the committee, has not only struggled along on his own, but is overwhelmed and fatigued not only by the constant technological change, but also the negative experiences that he has had in trying to integrate the previous 
mandating of technology into his courses. He has never really dabbled with technology outside his work life; indeed, he has never really had the finances to do so. He feels coerced to adopt things for the sake of rapid change; his face-to-face teaching is the only area that he feels he has any skill and agency in.

The terms equality and equity are often misunderstood. Each concept carries implicit assumptions relating to what is fair, including implications about how individuals should be treated, and how resources should be distributed, in a given context (Levitan, 2015). Equality relates to the notion of sameness; in this, the provision that fairness and justice are achieved by giving everyone the same. This, however, is only fair and just if everyone commences at the same starting point. Unfortunately, the playing field is not level (Willems, 2004, 2011) and it is the causes and consequences that raise issues of injustice (Young, 2001). In contrast, the notion of equity requires shifting to a paradigm of equity (Gorski, 2005), which acknowledges the various needs of individuals, thereby acknowledging the unevenness of the playing field. This includes the differing types of specific equipment or support required to achieve meeting these needs (Levitan, 2015).

Through the lens of education, educational equity relates to access, participation, and successful outcomes in education. The Organisation for Economic Co-operation and Development (OECD, 2008) describes educational equity as having two intertwined strands of fairness and inclusion. Fairness relates to ensuring that "personal and social circumstances - for example gender, socio-economic status or ethnic origin should not be an obstacle" (p. 2). Inclusion, in turn, relates to ensuring a basic minimum standard for all in the context of education (OECD, 2008). Redressing this inequality on a global scale is one of the United Nations' Sustainable Development Goals (United Nations, 2015).

We live in a digital era wherein technology increasingly infuses every facet of life, including education. In order to redress educational equity, we must also consider addressing the issue of digital equity which remains a complex, "wicked" problem (Alexander et al., 2019). Digital equity is defined as "equal access and opportunity to digital tools, resources, and services to increase digital knowledge, awareness, and skills" (Davis, Fuller, Jackson, Pittman, \& Sweet, 2007). This relates not simply to a fair distribution of resources based on needs, but also encompasses not only access and distribution to equipment and the Internet, but also unbiased and uncensored content (Alexander et al., 2019. In addition, it also relates to having awareness, skills and knowledge to be able to fully utilise these for educational purposes. Yet educational inequities still persist (Selwyn, 2016). As a consequence, digital equity is considered to be a civil rights issue of the modern era. Indeed, in the 2018 Horizon Report (Adams Becker et al., 2018), digital equity was recognised as being a significant challenge; one that is impeding the adoption of digital technologies in higher education around the globe.

Concerns around participation of students across all education sectors as a digital equity issue were first raised in the 1980s and 1990s (Selwyn, 2004). The acknowledgement of the emergent digital divide - the gap between the haves and have-nots - included access to computer hardware, software and connectivity. By the turn of the century, theorists in the fields of multicultural education, critical theory and feminist studies (see further: Spender, 1995), were all contributing to the expansion of the concept of digital equity and the digital divide. Their scholarship, and that of others since, has helped shape notions of digital equity away from simplistic views around hardware and connectivity (see further: Gorski, 2009) to refocus our understanding of it as a complex and multidimensional issue (see further: Willems, 2010). Graham (2011) suggested a re-theorisation of the digital divide into two domains: first, the physical and material divides that separate individuals from access to cyberspaces; and second, the virtual or cyber divides "that obstruct movement between cyberspaces of the knowledge divide" (pp. 220-222). With these evolved understandings comes the need for a revised notion of the digital divide; one that acknowledges "the hybrid, scattered, ordered and individualized nature of cyberspaces" (Graham, 2011, p. 211). As Makinen (2006) has noted, bridging gaps in physical access to technologies is not sufficient a solution to the complex problem, especially "if we fail to address the gaps in opportunity actually to use the technologies in ways that empower people to participate more fully and equitably" (Gorski, 2009, p. 352).

As universities increasingly move to online operations and offerings, access to higher education also encompasses having the requisite technology, the connectivity necessary to participate, and the knowledge and skills to do so. However, while much of the discussions around the digital divide in tertiary education have related predominantly to the students themselves, digital equity as an issue for staff has received less attention in the literature (Willems, 2011). When it is discussed, it often relates to the digital divide in terms 
of a comparison between students and staff and/or in terms of digital immigrants attempting to colonise the world of digital natives (see further: Prensky, 2001). However, considerations of the digital divide or, conversely, digital equity, are very much a consideration for staff as well. Facets such as geographical dispersion or isolation, varying physical abilities, technological diversity, technological access, and in addition to variances in knowledge, skills, competence, and confidence, all play a role.

\section{An equity-based approach to staff capacity building requires empathy}

Equity in education requires empathy (Carter, 2015). Empathy involves understanding difference and personal variations between self and others by the fostering of mutual respect (Matthews, 2006). Davis (1983, pp. 113-114) argued that empathy encompasses both cognitive and affective (emotional) dimensions, including perspective-taking or taking the "psychological point of view of others", and empathic concern, which involves "feelings of sympathy and concern for unfortunate others". In contrast to a worldly emphasis on individualism, empathy is the ability to understand another's thoughts, feelings and behaviours which, in turn, foster prosocial actions driven through compassion.

Empathy is necessary for providing an environment conducive to learning and transformation (Arnold, 2005), and this includes staff professional development. The use of narrative in sharing the staff vignettes at the start of this article - all derived from personal experience - is not coincidental. Narrative scholars have argued that the key to being empathetic is the ability to gather, interpret, and translate the stories of others (DasGupta \& Charon, 2004); as "empathetic witnessing" (Kleinman, 1988, p. 54). Schlesinger (1984) has argued that empathy involves having a sensitive regard for others, through having an awareness of their needs, being alert to how they may be feeling in the process and accommodating these needs. Arnold (2005) described empathy as actions with thoughtful, heartfelt imaginations.

Empathetic understanding of staff diversity and the variety of issues that they face on a daily basis is a crucial element in the development of professional processes to upskill staff in technology-enhanced learning. Without it, the risk is staff alienation. Empathy involves a variance in the traditional approach to staff professional development, drawing on personal agency of staff, rather than an imperialistic, transmissive approach which may lead to resistance. Prusko (2018) concurred, arguing that we must reimagine the faculty development experience if we want to increase attendance and engagement by staff. She suggested a service design methodological approach to staff professional development, rather than the traditional transmissive style, in which the focus is on an "an iterative process of storytelling, brainstorming, and prototyping to reimagine a service" (Prusko, 2018, p. 2). She continued that the benefits of such an approach enable staff:

to gain empathy for faculty, understand their pain points, and develop meaningful, humancentered services that solve the real problem. Empathy enables us to build relationships of trust and be seen as solution partners. This process requires a safe space for faculty to be vulnerable and share their story, and time for exploration, brainstorming, and thoughtful failure. (p. 2)

However, for an equity-based approach, empathy is not simply a cognitive process - the aha moment - but it also needs to accompany action (Matthews, 2006). It involves the co-construction of the staff professional development processes based on achieving the shared needs of staff. Webster-Wright (2009, p. 727) argued that "If the agentic roles of professionals in shaping their learning is to be taken seriously, then a framework of support needs to account for this whilst working within contextual constraints". This speaks to inclusive learning opportunities. As Hockings (2010, p. 1) described, this embraces "a view of the individual and individual difference as the source of diversity that can enrich the lives and learning of others". On the flip side, and with consideration for diversity, it also recognises the possibility of utilising pedagogical approaches that do not adopt the mandated technology. For while it is important for staff to learn about technology for teaching and learning, they may, in their agentic role, decide to not end up using it.

In addition to building an understanding and competence of the use of the technology for teaching and learning in higher education, it is important to emphasise that accessibility and universal design are the new normal, and not a retrofitted afterthought. Indeed, the 2018 Educause Learning Initiative study (ELI, 2018) reported that while issues of staff professional development and academic transformation continue to run at or near the top of the list of concerns, the key issue of accessibility and universal design for learning has 
made a dramatic ascent over the past 4 years, moving from number 12 in the rankings for concern in 2015 up to number 2 in 2018. This indicates an urgency for educating the academic community in the use of effective practices and course designs that are accessible by everyone. Accessibility is part of the suite of digital considerations to overcome the divide for all - for staff and students alike.

Other aspects of this nebulous issue encompass the importance of staff understanding the implications of using technology for both themselves, and for their students. There is a moral imperative for staff to learn about the use of technology, not only so that they can use it in their teaching but so that they are better able to keep themselves and their students safe. The use of social media is a case in point (Willems \& Bateman, 2013). The use of technology in which accessibility is a guiding principle is also a good reason for staff to overcome any reluctance and to develop technological literacy.

\section{Capacity building of staff to overcome issues in the digital divide}

\section{Provision of professional development for staff}

Social justice from a transformative viewpoint seeks to redress the root causes that have led to a lack of participatory parity (Fraser, 2009; Leibowitz \& Bozelak, 2016). The lack of a nuanced staff professional development program is a digital equity issue in its own right. Factoring in such staff diversity and individual needs is crucial for institutions in the consideration of aiding student learning. Staff capacity building - also referred to as staff development, professional development (Australasian Council on Open, Distance and e-learning [ACODE], 2014) or faculty development - is a challenging space wherein academic and support staff (also referred to as professional staff in different institutions) are often joined for the delivery of learning to their colleagues. The Educause Learning Initiative (ELI, https://www.educause.edu/eli) - in their annual survey about what is most exciting, pressing, consequential, and relevant in advancing learning through technology in higher education, have - since 2011, noted staff professional development as remaining at, or near, the top of the list of continuing concerns for the higher education sector to be attended to (ELI, 2018). It is clear that explicit attention is required to the considered and nuanced development of staff in relation to using technology in their teaching.

Institutions have a responsibility to develop technological skills and pedagogical capabilities of staff to support the learning needs of increasingly diverse student cohorts in order to better engage students (Cleary, Samarawickrema, \& Gauci, 2017), and assist staff too. Capacity building through staff professional development has been a well-regarded strategy to promote and support change in education through knowledge building, empowering and supporting educators (Bossu \& Willems, 2017). In context, activities for the capacity building of staff include face-to-face, blended and online opportunities that can be selfdirected or institutionally mandated. They can be for individuals or groups. Some of these offerings will be nuanced to meet the needs arising for teaching staff, while others will be based upon the strategic needs of the organisation (ACODE, 2014). Some professional development will be overarching and come from central units of teaching and learning within the university, while other development will be provided by faculty and units within faculties adopting a more hands-on, managed approach (Bothma \& Cant, 2011). In addition, we are seeing an increase in the provision of staff professional development via outsourced third-party opportunities, such as vendor offerings and open education opportunities and resources such as those provided by massive open online courses (MOOCs) (Annabi \& Wilkins, 2016). Ideally, staff professional development in the use of new technologies for teaching and learning ideally is part of a continuing professional development curriculum, scaffolded in such a way as to meet the differing values, skills, and needs of staff, and in their various roles.

The consideration of diversity in terms of digital equity needs to be factored into such professional development. This includes acknowledging the differing needs and abilities of staff involved. This program would be informed by the work of those involved, offer flexibility, would accommodate a range of entry points, and would be evaluated, rather than be limited by factors of physical location, equity or technological skills (ACODE, 2014).

In attempts to set guidance on this matter, ACODE (2014) has proposed a number of benchmarks "to support continuous quality improvement in technology enhanced learning” (p. 4). Of these, Benchmark 5 specifically relates to staff professional development around technology-enhanced learning. Benchmark 5 states, "Quality learning and teaching is brought about where people are confident, enthusiastic, skilled and 
well supported, and learning experiences are designed to engage the learner and employ a variety of approaches" (p. 28). The performance indicators to demonstrate the achievement of this benchmark include the recommendations that staff professional development is delivered flexibly and addresses differing skill levels:

(1) A framework for staff development in technology enhanced learning is part of the institution's learning and teaching strategy.

(2) Processes are in place and in use to identify staff development needs in support of the institution's strategy for technology enhanced learning.

(3) Educational and technical expertise is used to develop quality programs and resources addressing staff development needs.

(4) Coordination occurs between those areas providing staff development for technology enhanced learning across the institution.

(5) Staff development for technology enhanced learning is resourced.

(6) Staff development programs are delivered flexibly and address differing skill levels.

(7) Evaluation data is used to inform the planning for continuous improvement of staff development processes. (ACODE, 2014, p. 28)

Understanding the variety of needs and skills of staff in any professional development design is the same though process that we would follow for our students. One size does not fit all. Nor does a top-down delivery style work in the creation of staff development opportunities. Webster-Wright (2009, p. 702) argued that despite research findings about how professionals learn "many professional development practices still focus on delivering content rather than enhancing learning" and that in order to shift the focus, considerations of the variety of staff needs to take place. Hannon, Hirst, and Riddle (2011, p. 559) suggested that staff professional development in technology needs to move beyond "the dull, under resourced, IT driven, passive service approach" to one that fosters ownership. They suggested that rather than a passive approach, the alternative approach of fostering learning by doing be adopted; one which includes the scaffolding of professional development, "to encourage expansive thinking and novel solutions" (p. 559). Hunzicker (2011) suggested that professional development is effective when participants can engage not only cognitively but also physically and emotionally, with a leaning towards the sharing of views, problems, and ideas, and working together towards finding solutions.

\section{Personal agency in professional development}

The social justice goal of the digitally underempowered, or even disempowered, is to facilitate empowerment (Marullo \& Edwards, 2000). In higher education, many of the digital equity issues can be beyond the control and capacity of staff to alter. This may at first appear deterministic; that there may be little which can be done to address these external forces upon the individual. Yet the work of Bandura (1989) suggests that through personal agency, an individual can find solutions to change what one can. Bandura, describing personal agency, noted that it can be:

achieved through reflective and regulative thought, the skills at one's command, and other tools of self-influence that affect choice and support selected courses of action. Selfgenerated influences operate deterministically on behavior the same way as external sources of influence do... It is because self-influence operates deterministically on action that some measure of self-directedness and freedom is possible. (p. 1182)

That is, through personal agency, there are things that staff can do to change their situation both reactively and proactively to empower themselves, and others, in spite of the factors external to their own control or influence, such as institutional technology choices, cultures and policy. One solution for a staff-led approach to address such issues, and empower others, is the creation of a robust professional development program on digital technology to help stem the digital divide between staff haves and have-nots so that they can participate in the workplace fully and equitably.

Driven by a needs and skills analysis to identify technological issues encountered by staff in their daily work functions and existing skills gaps, some issues to consider in the constructions of technology-related professional development programs is to examine the existing offerings through the lens of various 
underrepresented and underempowered sub-groups of the academic workforce to see where the program weaknesses are. The questions needing to be asked include:

- Can all staff access the professional development physically and/or virtually the content?

- Is flexible participation a possibility?

- Where skill development is the target, is the learning scaffolded appropriately?

- What presumptions is the professional development based upon?

- Do all staff have supported access to the technology (hardware and software)?

- Do staff feel that they are supported in the growing development of their knowledge and skills?

- Do staff understand why it is important that they have these skills and knowledge?

- Is the content created in such a way that it can be accessed by those who it is intended to target?

The list goes on.

\section{Discussion}

In order to understand the impediments to adoption of technology, staff input is necessary to avert simplistic assumptions on lack of engagement, particularly in terms of assumptions of staff attitude. We need to listen to the different staff voices on this issue as those more reluctant (such as Dianne and George in the example) may be justified in their views. So, let's return to the scene of the faculty teaching and learning meeting at the start of this article to draw this together, starting with George first.

How would a staff member like George respond to both the idea that staff on the ground should sort out their own staff development programs, and to the resultant staff-led programs themselves? George is a great educator and has skills that are important not to overlook in the adoption of technology. His agency is in his passion for teaching. Dianne similarly is an important voice to heed. She has some very real challenges to overcome. She provides great value for the university - a committed and dedicated staff member who commutes long hours. She knows too well the hurdles and will be a great source of understanding what could be done to help and assist staff in her position - if only she would be asked. Her opinions and solutions matter. For these reasons, staff like George and Dianne need to be part of collaborative task forces so that their concerns are noted and solutions sourced if adoption of a given technology is given the go-ahead.

Viv is in an ideal situation. Staff such as Viv can provide balance for both sides of the spectrum. While she goes along with the majority, she does have a compassionate heart. She just has not had the opportunity to hear or understand what some of the barriers are that colleagues like George and Dianne are facing. While fairly competent with technology for teaching and learning, Viv does, however, come from a minority group in higher education, and those understandings could help her empower other staff.

It is perhaps easier for staff such as Ben, who has taught the same classes for a length of time, to have the opportunity to creatively explore and understand potential technologies for teaching and learning. Ben is in a privileged position, though may not be aware of it, or conversely may be guarding it. With Ben's drive and stability of teaching - not have to develop and teach a variety of content continuously as other colleagues may have to - may give rise to opportunities for him to buddy with and support over-extended colleagues in their personal professional development. How do we bring experienced and technologically equipped staff like Jen along for the ride? Like Ben, Jen might need opportunities to give back to the community. Colleagues such as Jen and Ben might also benefit from the opportunity to walk in another's shoes, so as to understand first-hand the challenges being faced by others, and/or witness the very real concerns that they are expressing (or at least would if they had the opportunity). For without such insights, empathy for others may not grow. Successful leaders who have empathy will demonstrate understanding, respect for, and support for another's ideas, and appreciation of the other's experiences (Undung \& De Guzman, 2009).

\section{Suggested additional performance indicators to ACODE's Benchmark 5}

Through this alternative lens of digital equity, the arguments made throughout this article suggest four additional performance indicators for staff professional development in the effective use of technologyenhanced learning be added to ACODE's Benchmark 5. These will ensure that staff professional 
development is organised in consideration of the digital divide and the need for digital equity. To achieve these, however, resourcing may need to be unevenly distributed (equity) rather evenly distributed (equality). These additional performance indicators for inclusion in ACODE's Benchmark 5 are shown in italics interspersed with the existing indicators in the following list:

1. A framework for staff development in technology enhanced learning is part of the institution's learning and teaching strategy.

2. An empathetic assessment of variance in staff needs for professional development helps identify staff inhibitors and roadblocks in order to progress digital equity.

3. Processes are in place and in use to identify staff development needs in support of the institution's strategy for technology enhanced learning.

4. Educational and technical expertise is used to develop quality programs and resources addressing staff development needs.

5. Coordination occurs between those areas providing staff development for technology enhanced learning across the institution.

6. Staff development for technology enhanced learning is resourced.

7. Hardware, software and connectivity solutions for disadvantaged staff are also resourced.

8. Staff professional development programs are delivered flexibly and address differing skill levels

9. Staff professional development programs that foster input and participation to build personal agency.

10. Institutions put in place considerations to avert technological change fatigue in staff.

11. Evaluation data is used to inform the planning for continuous improvement of staff development processes.

To ensure justice for staff in higher education requires an examination of all practices, for employment at an institution is not necessarily a safeguard of staff from the digital divide. Staff reluctance about the use of new technologies may not simply be recalcitrance on their part. It may be masking a systemic digital divide. As Patton, Shahjahan, and Osei-Kofi (2010) noted, "[t]o effectively understand and work toward social justice in higher education, we need to understand and evaluate the institutional processes, the patterns of distribution, social relations, and cultural/societal norms... within the higher education system" (p. 269). Staff professional development, if not carefully considered, may fall foul of this. Staff need to be able to access the technologies themselves, and receive effective, scaffolded professional development, targeted to meet the varying needs. Concrete recommendations for exposing and addressing such a divide within an institution is the focus of ongoing research.

\section{A final cautionary note}

Part of the development of digital equity, including digital literacy, in the modern era of higher education must be the ability of staff to appropriately and safely resist or refute its use and/or wider adoption. This issue seems particularly pertinent to social justice, given the pervasive possibilities, surveillance, monitoring, and subtle coercion of behaviour that we are witnessing in today's society. Staff can be monitored: Emails, browser histories, files accessed, freedom of speech on social media. These are all very real concerns in the current day (Tanczer, McConville, \& Maynard, 2016).

\section{Conclusion}

The landscape of teaching and learning in higher education is ever changing due to the introduction of new technology. To help attend to digital equity as a social justice issue (Gorski, 2005), we must acknowledge that it is a concern not only for our students, but also staff. Care is needed to ensure that the digital divide does not marginalise the very people who are tasked with contributing to the successful learning outcomes of enrolled students, by leaving them behind. Indeed, employment at an institution does not necessarily safeguard staff from the digital divide. We need to understand more deeply "how our assumptions, decisions, and practices contribute to, or challenge, systems of control and domination by people historically and presently privileged by the education system" (Gorski, 2005, p. 6).

To bolster technological empowerment, staff need to be able to access targeted and nuanced professional development in order to build capability and capacity with new forms of technologies, learning spaces, learning design and new pedagogies. The building of a robust technology-related professional development 
program helps to address these complex challenges by scaffolding knowledge and skills and assisting access to and use of technology tools (Morewood, Ankrum \& Dagen, 2017). It also helps address one of the issues highlighted as part of empowering the disadvantaged - and that is social connectivity - so that "the individual and community are fundamentally connected" (Page \& Czuba, 1999, p. 1). The value of staff empowering staff through the development of their own digital technology professional development programs driven by localised needs analysis is that it meets some of the objectives in overcoming underempowerment by the reduction of staff isolation and potential alienation from others and the institution by helping them feel connected and part of the whole. It is a means of overcoming helplessness and fostering personal agency. As Marullo and Edwards (2000) summed up, "[s]uch changes are to come about through altering institutional arrangements by redistributing resources and enhancing capacities of those with less, so that such institutional operations no longer maintain such inequities" (p. 898).

Staff also need to be able to access the technologies themselves. Promoting awareness of this issue through publication and research is a way in which these challenges can begin to become visible and start being addressed; indeed, it is an area that requires ongoing research. This may even be the simple provision of Wi-Fi for those commuting long distances so that colleagues such as Dianne are still able to contribute in the workforce without additional hurdles or undertake institutional work borne at their own personal expense (for example, using personal phone data for Wi-Fi connectivity). If institutions of higher education wish to be seen as actively striving to overcome aspects of digital inequities, then these inconsistencies need to be identified, articulated, faced, and actively pursued and not only for students, but for staff as well. Let's continue to keep these issues at the forefront of our collective attentions, striving continually to tackle this wicked problem.

\section{Acknowledgements}

The author is appreciative of the guidance and insights of the AJET blind peer reviewers in the strengthening this article.

\section{References}

Adams Becker, S., Brown, M., Dahlstrom, E., Davis, A., DePaul, K., Diaz, V., \& Pomerantz, J. (2018). Horizon Report 2018: Higher Education Edition. Louisville, CO: EDUCAUSE. Retrieved from https://www.learntechlib.org/p/184633/

Alexander, B., Ashford-Rowe, K., Barajas-Murphy, N., Dobbin, G., Knott, J., McCormack, M., Pomerantz, J., Seilhamer, R., \& Weber, N. (2019). Horizon Report: 2019 Higher education edition. Louisville, CO: EDUCAUSE. Retrieved from https://library.educause.edu/resources/2019/4/2019horizon-report

Annabi, C. A., \& Wilkins, S. (2016). The use of MOOCs in transnational higher education for accreditation of prior learning, programme delivery, and professional development. International Journal of Educational Management, 30(6), 959-975. https://doi.org/10.1108/IJEM-05-2015-0057

Arnold, R. (2005). Empathic intelligence: Teaching, learning, relating. Sydney, Australia: University of New South Wales Press.

Australasian Council on Open, Distance and e-learning. (2014). Benchmarks for technology enhanced learning. Canberra: Author. Retrieved from https://www.acode.edu.au/pluginfile.php/550/mod_resource/content $/ 8 /$ TEL_Benchmarks.pdf

Bandura, A. (1989). Human agency is social cognitive theory. American Psychologist, 44(9), 1175- 1184. https://doi.org/10.1037/0003-066X.44.9.1175

Bossu, C., \& Willems, J. (2017). OER based capacity building to overcome staff equity and access issues in higher education. In H. Partridge, K. Davis, \& J. Thomas. (Eds.), Me, Us, IT! Proceedings of ASCILITE 2017, the International Conference on Innovation, Practice and Research in the Use of Educational Technologies in Tertiary Education (pp. 22-26). Retrieved from http://2017conference.ascilite.org/wp-content/uploads/2017/11/Concise-BOSSU.pdf

Bothma, C. H., \& Cant, M. C. (2011). Adopting learning technologies: From belief to practice. Educational Studies, 37(4), 375-389. https://doi.org/10.1080/03055698.2010.511697

Carter, P. L. (2015). Educational equity demands empathy. Contexts: Understanding People in their Social Worlds, 14(4), 76-78. https://doi.org/10.1177/1536504215611893 
Cleary, K., Samarawickrema, G., \& Gauci, S. (2017). Us and IT: Capacity-building for blended learning: An intersection between educator, pedagogy, and technology. In H. Partridge, K. Davis, \& J. Thomas. (Eds.), Me, Us, IT! Proceedings of ASCILITE 2017, the International Conference on Innovation, Practice and Research in the Use of Educational Technologies in Tertiary Education (pp. 32-36). Retrieved from http://2017conference.ascilite.org/wp-content/uploads/2017/11/Concise-CLEARY.pdf

Daly, C., Pachler, N., \& Pelletier, C. (2009). Continuing professional development in ICT for teachers: A literature review. London, United Kingdom: Becta.

DasGupta, S., \& Charon, R. (2004). Personal illness narratives: Using reflective writing to teach empathy. Academic Medicine, 79(4), 351-356. Retrieved from https://journals.lww.com/academicmedicine/Fulltext/2004/04000/Personal_Illness_Narratives_Using_ Reflective.13.aspx

Davis, M. (1983). Measuring individual differences in empathy: evidence for a multidimensional approach. Journal of Personality and Social Psychology, 44(1), 113-126. https://psycnet.apa.org/doi/10.1037/0022-3514.44.1.113

Davis, T., Fuller, M., Jackson, S., Pittman, J., \& Sweet, J. (2007). A national consideration of digital equity. Eugene, OR: International Society for Technology in Education. Retrieved from ERIC database. (ED497214)

Educause Learning Initiative. (2018). The 2018 key issues in teaching and learning. Retrieved from https://library.educause.edu/ /media/files/library/2018/1/eli7153.pdf

Fraser, N. (2009). Scales of justice: Reimagining political space in a globalizing world. New York, NY: Columbia University Press.

Gorski, P. (2005). Education equity and the digital divide. AACE Journal, 13(1), 3-45. Retrieved from from chttps://psycnet.apa.org/doi/10.1037/0022-3514.44.1.113

Gorski, P.C. (2009). Insisting on digital equity: Reframing the dominant discourse on multicultural education and technology. Urban Education, 44(3), 348-364. https://doi.org/10.1177/0042085908318712

Graham, M. (2011). Time machines and virtual portals: The spatialities of the digital divide. Progress in Development Studies, 11(3), 211-227. https://doi.org/146499341001100303

Hannon, J., Hirst, D., \& Riddle, M. (2011). Implementing e-learning: A migration story. In G. Williams, P. Statham, N. Brown, \& B. Cleland (Eds.), Changing Demands, Changing Directions: Proceedings of the ASCILITE 2011 Conference (pp. 557-561). Retrieved from http://www.ascilite.org/conferences/hobart11/downloads/papers/Hannon-concise.pdf

Hockings, C. (2010). Inclusive learning and teaching in higher education: A synthesis of research. Retrieved from https://s3.eu-west-2.amazonaws.com/assets.creode.advancehe-documentmanager/documents/hea/private/inclusive teaching and learning in he synthesis $200410 \quad 0 \quad 15680$ 37026.pdf

Hunzicker, J. (2011). Effective professional development for teachers: a checklist. Professional Development in Education, 37(2), 177-179. https://doi.org/10.1080/19415257.2010.523955

Kleinman A. (1988). The illness narratives: Suffering, healing and the human condition. New York, NY: Basic Books.

Leibowitz, B., \& Bozalek, V. (2016). The scholarship of teaching and learning from a social justice perspective. Teaching in Higher Education, 21(2), 109-122. https://doi.org/10.1080/13562517.2015.1115971

Levitan, J. (2015, May 2). The difference between educational equality, equity, and justice... and why it matters [Blog post]. Forum of the American Journal of Education. Retrieved from http://www.ajeforum.com/the-difference-between-educational-equality-equity-and-justice-and-why-itmatters-by-joseph-levitan/

Makinen, M. (2006). Digital empowerment as a process for enhancing citizens' participation. E- learning, 3(3), 381-395. https://doi.org/10.2304/elea.2006.3.3.381

Marullo, S., \& Edwards, B. (2000). From charity to justice. American Behavioral Scientist, 43(5), 895912. https://doi.org/10.1177/00027640021955540

Matthews, B. (2006). Engaging education: Developing emotional literacy, equity and co-education. Maidenhead, United Kingdom: Open University Press.

Morewood, A. L., Ankrum, J., \& Dagen, A. S. (2017). Aligning effective professional development and online learning: A conceptual stance. In C. Martin, \& D. Polly (Eds.), Handbook of research on teacher education and professional development (pp. 428-440). Hershey, PA: IGI Global. https://doi.org/10.4018/978-1-5225-1067-3.ch024 
Organisation for Economic Co-operation and Development. (2008). Policy Brief: Ten steps to Equity in Education. http://www.oecd.org/education/school/39989494.pdf

Page, N., \& Czuba, C. E. (1999). Empowerment: What it is? Journal of Extension, 37(5), 1-7. Retrieved from ERIC database. (EJ594508)

Patton, L., Shahjahan, R., \& Osei-Kofi, N. (2010). Emergent approaches to diversity and social justice in higher education. Equity and Excellence in Education, 43(3), 265-278. https://doi.org/10.1080/10665684.2010.496692

Prensky, M. (2001). Digital natives, digital immigrants: Do they really think different? On the Horizon, 9(6), 1-6. https://doi.org/10.1108/10748120110424816

Prusko, P.T. (2018). Faculty development. In The 2018 key issues in teaching and learning (p. 2). Louisville, CO: Educause Learning Initiative. Retrieved from https://library.educause.edu/ /media/files/library/2018/1/eli7153.pdf

Rogers, E.M. (2003). Diffusion of innovation (5th ed.). New York, NY: Free Press.

Schlesinger, H. J. (1984). The process of empathic response. In J. Lichtenberg, M. Bornstein, \& D. Silver (Eds.), Empathy II (pp. 187-216). Mahwah, NJ: Lawrence Erlbaum.

Selwyn, N. (2004). Reconsidering political and popular understandings of the digital divide. New Media \& Society, 6(3), 341-362. https://doi.org/10.1177/1461444804042519

Selwyn, N. (2016). Education and technology: Key issues and debates. London, United Kingdom: Bloomsbury.

Spender, D. (1995). Nattering on the Net: Women, power and cyberspace. Melbourne, Australia: Spinifex Press.

Tanczer, L. M., McConville, R., \& Maynard, P. (2016). Censorship and surveillance in the digital age: The technological challenges for academics. Journal of Global Security Studies, 1(4), 346-355. https://doi.org/10.1093/jogss/ogw016

Undung, Y., \& De Guzman, A.B. (2009). Understanding the elements as a component of care driven leadership. Journal of Leadership Studies, 3(1), 19-28. https://doi.org/10.1002/jls.20092

United Nations. (2015). Sustainable development goals. Retrieved from https://sustainabledevelopment.un.org

Webster-Wright, A. (2009). Reframing professional development through understanding authentic professional learning. Review of Educational Research, 79(2), 702-739. https://doi.org/10.3102/0034654308330970

Willems, J. (2004). Looking from the outside in: The Issue of equal access to computer-mediated learning by distance learners in higher education (Master's dissertation). Retrieved from https://rune.une.edu.au/web/handle/1959.11/21612

Willems, J. (2010). The equity raw-score matrix: A multidimensional indicator of potential disadvantage in higher education. HERDSA Journal, 29(6), 603-621. https://doi.org/10.1080/07294361003592058

Willems, J. (2011). Equity: A key benchmark for students and staff in an era of changing demands, changing directions. In G. Williams, P. Statham, N. Brown, \& B. Cleland (Eds.), Changing Demands, Changing Directions: Proceedings of the ASCILITE 2011 Conference (pp. 1305-1311). Retrieved from http://www.ascilite.org/conferences/hobart11/downloads/papers/Willems-full.pdf

Willems, J., \& Bateman, D. (2013). Facing up to it: The practice of blending formal and informal learning opportunities in higher education contexts. In G. Trentin \& M. Repetto (Eds.), Using network and mobile technology to bridge formal and informal learning (pp. 53-79). Oxford, United Kingdom: Chandos.

Young, I. M. (2001). Equality of whom? Social groups and judgments of injustice. Journal of Political Philosophy, 9(1), 1-18. https://doi.org/10.1111/1467-9760.00115

Corresponding author: Julie Willems, Julie.Willems@,monash.edu

Copyright: Articles published in the Australasian Journal of Educational Technology (AJET) are available under Creative Commons Attribution Non-Commercial No Derivatives Licence (CC BY-NC-ND 4.0). Authors retain copyright in their work and grant AJET right of first publication under CC BY-NC-ND 4.0.

Please cite as: Willems. J. (2019). Digital equity: Considering the needs of staff as a social justice issue. Australasian Journal of Educational Technology, 35(6), 150-160. https://doi.org/10.14742/ajet.5503 